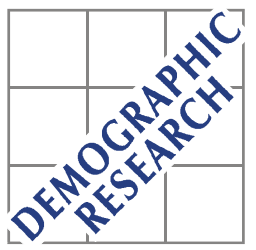

Demographic Research a free, expedited, online journal of peer-reviewed research and commentary in the population sciences published by the Max Planck Institute for Demographic Research Konrad-Zuse Str. 1, D-18057 Rostock · GERMANY www.demographic-research.org

DEMOGRAPHIC RESEARCH

VOLUME 24, ARTICLE 17, PAGE 407

PUBLISHED 8 MARCH 2011

http://www.demographic-research.org/Volumes/Vol24/17/

DOI: 10.4054/DemRes.2011.24.17

Editorial

\title{
An editorial on plagiarism
}

Nico Keilman

Andrew Hinde

Joshua Goldstein

(C) 2011 Nico Keilman, Andrew Hinde \& Joshua Goldstein.

This open-access work is published under the terms of the Creative Commons Attribution NonCommercial License 2.0 Germany, which permits use, reproduction \& distribution in any medium for non-commercial purposes, provided the original author(s) and source are given credit.

See http:// creativecommons.org/licenses/by-nc/2.0/de/ 


\title{
An editorial on plagiarism
}

\author{
Nico Keilman \\ Andrew Hinde \\ Joshua Goldstein
}

\section{Editorial}

In January this year, we were confronted with a case of plagiarism. One paper that had been submitted last year by a certain person turned out to be written by three other persons. It was presented by the three true authors at a conference in 2010, where they distributed copies of their paper. One of the reviewers of the paper informed us about that fact. We asked the three authors for a copy, which turned out to be identical with the submission, except for a few minor details. When confronted with these facts, the person who had submitted the paper was unable to give us a satisfactory explanation.

This is a case of serious scientific misconduct. The editors and the publisher of Demographic Research cannot and will not accept any form of plagiarism. Nor will we accept any other form of misconduct in science, including fabrication, falsification, or other practices that seriously deviate from those that are commonly accepted within the scientific community for proposing, conducting, or reporting research. With Long et al. ("Responding to possible plagiarism", Science 6 March 2009), we are of the opinion that the responsibility for research integrity ultimately lies in the hands of the scientific community: educators, students, authors, and those who provide peer reviews. Journal editors must take appropriate action and verify the originality of suspected manuscripts. The Office of Research Integrity provides useful guidelines (http://ori.dhhs.gov/).

We have decided that any future submission to Demographic Research that lists the plagiarist as an author or co-author will be rejected automatically.

Nico Keilman, editor

Andrew Hinde, associate editor

Joshua Goldstein, publisher 